\title{
WEIGHT, HEIGHT AND NUTRITION.
}

\author{
OBSERVATIONS FROM THE ISLE OF ELY.
}

\author{
By ThOMAS C. LONIE, M.B., Сн.B., D.P.H., \\ Assistant County Medical Officer, Isle of Ely County Council.
}

THE Isle of Ely is the northern half of the geographical County of Cambridgeshire and forms in itself a separate administrative county. It is the heart of the fen country, and its population is one which long retained a degree of isolation and independence tending to preserve in its members certain mental, and perhaps physical characters peculiar to themselves. It is interesting to recall that from this neighbourhood came Boadicea, Queen of the Iceni, and Hereward the Wake, who proved such stubborn enemies to the conquerors of their country.

In 1933 an investigation was undertaken for the purpose of arriving at normal standards of height and weight of elementary school children for this area, and, by deduction, at the apparent amount of malnutrition existing within it.

\section{Method OF COLLECTION OF THE DATA.}

The data were collected for the most part during a special series of visits to the schools, though a few were obtained during the routine medical examinations. In all, over 5000 children were measured.

For the weighings a short lever machine of known accuracy was used. The type of machine adopted is, I believe, of importance. Spring machines of the "personal" weighing type are in use in many of the schools in this area. The objections to these are:

(1) They are frequently not properly adjusted.

(2) Where there is an error this is generally not a constant one but varies with the weight.

(3) It is difficult to read the weight to the required degree of accuracy since the whole dial in the pattern in use here is less than 6 in. in diameter, and a length of $\frac{3}{4}$ in. only is allowed for each $14 \mathrm{lb}$. It seems obvious that the source of error must be very considerable, for it is certainly impossible to read a weight more accurately than to the nearest pound.

(4) Personal observation shows that by varying slightly one's position on the machine a difference of about $2 \mathrm{lb}$. can be made in the weight recorded.

(5) Since in this type of machine the figures on the dial are reversed, and are read from their reflection in a mirror, a further source of possible error is introduced.

The sources of error in taking heights are not so great, but the standards already existing in the schools were checked for the purpose of the present 
study. Heights were taken to the nearest $\frac{1}{2}$ in. and weights to the nearest $\frac{1}{2} \mathrm{lb}$. The weights and heights were entered on individual cards together with the name, date of birth, and date of examination. The sexes were distinguished by the use of blue cards for boys and pink for girls. In compiling the tables it was found convenient to utilise merely whole numbers, thus, heights of 50 in. included those previously recorded as 50 and 50.5 in. From the method of recording it will be seen that the midpoint of the whole group would be $50 \cdot 25$ in. Similar reasoning applies to the recorded weights. In arriving at the final figures for the means, this grouping was allowed for. All measurements were made in ordinary indoor clothing without boots.

Since about half the total school population was measured, and since the schools were representative and were situated in all areas of the county, the resulting figures may be taken as representative of the height and weight of children in this part of the county.

Tables I and II have been constructed to show mean weight and height at ages for each sex together with standard deviations and coefficients of variation for each age group. The coefficients of correlation and the regression of weight on height for each age group have also been calculated. The age shown represents the midpoint of each group, thus, the age 8 group consists of those children whose ages range from over 7 years and 9 months up to and including those of 8 years and 3 months. Similarly the ages in the comparative tables represent in all cases the midpoint of the group.

\section{Height.}

A study of the observations of height in both sexes (Tables I and II) shows that girls in this area are taller than boys from about age 10 to 14 years (the limit of the observations). Below 10 years in most groups the boys are taller than the girls. For instance in the age groups 5 to 9.5 the boys are on the average $0 \cdot 20$ in. taller; at 10 to $11 \frac{1}{2}$ the girls are $0 \cdot 24$ in. taller and at 12 to 14 the girls have an advantage of 0.96 in. The differences in the rate of growth can be clearly seen in the following figures where comparison of the observations is made with published data from East Sussex (vide Dunstan, 1925).

Increase in height.

\begin{tabular}{|c|c|c|c|c|}
\hline \multirow[b]{2}{*}{ Age } & \multicolumn{2}{|c|}{ Boys } & \multicolumn{2}{|c|}{ Girls } \\
\hline & $\begin{array}{r}\text { Isle of Ely } \\
\text { To }\end{array}$ & $\begin{array}{l}\text { East Sussex } \\
\text { l increase in }\end{array}$ & $\begin{array}{l}\text { Isle of Ely } \\
\text { hes. }\end{array}$ & East Sussex \\
\hline $\begin{array}{l}6-9 \\
9-13\end{array}$ & $\begin{array}{l}6 \cdot 6 \\
8 \cdot 3\end{array}$ & $\begin{array}{l}6 \cdot 2 \\
7 \cdot 3\end{array}$ & $\begin{array}{l}6 \cdot 5 \\
9 \cdot 5\end{array}$ & $\begin{array}{l}6 \cdot 1 \\
8 \cdot 8\end{array}$ \\
\hline \multicolumn{5}{|c|}{ Mean increase in inches per year. } \\
\hline $\begin{array}{l}6-9 \\
9-13\end{array}$ & $\begin{array}{l}2 \cdot 20 \\
2 \cdot 08\end{array}$ & $\begin{array}{l}2 \cdot 07 \\
1 \cdot 83\end{array}$ & $\begin{array}{l}2 \cdot 16 \\
2 \cdot 38\end{array}$ & $\begin{array}{l}2 \cdot 03 \\
2 \cdot 20\end{array}$ \\
\hline
\end{tabular}

In both areas the average annual increase in height differs very little up to age 9 between the two sexes; on the whole the boys grow slightly faster. From 
age 9 to age 13 the rate of increase is distinctly greater in girls. In all cases the increases are greater in the Isle of Ely than in East Sussex.

Table I. Isle of Ely. Boys.

\begin{tabular}{|c|c|c|c|c|c|c|c|c|c|}
\hline \multirow{3}{*}{$\begin{array}{c}\text { Age in } \\
\text { years [age } \\
\text { shown is } \\
\text { midpoint } \\
\text { of group] } \\
\text { (1) }\end{array}$} & \multirow{3}{*}{$\begin{array}{l}\text { No. of } \\
\text { observa- } \\
\text { tions } \\
\text { (2) }\end{array}$} & \multicolumn{3}{|c|}{ Height in in. } & \multicolumn{3}{|c|}{ Weight in $\mathrm{lb}$. } & \multirow{3}{*}{$\begin{array}{l}\text { Coefficient } \\
\text { of correla- } \\
\text { tion between } \\
\text { height and } \\
\text { weight } \\
\text { (9) } \\
+\end{array}$} & \multirow{3}{*}{$\begin{array}{l}\text { Coefficient } \\
\text { of regres- } \\
\text { sion, weight } \\
\text { on height } \\
(10)\end{array}$} \\
\hline & & & & Coefficient & & & Coefficient & & \\
\hline & & $\begin{array}{c}\text { Mean } \\
(3)\end{array}$ & $\begin{array}{c}\text { Standard } \\
\text { deviation } \\
(4)\end{array}$ & $\begin{array}{c}\text { of } \\
\text { variation } \\
(5) \\
\%\end{array}$ & $\begin{array}{c}\text { Mean } \\
(6)\end{array}$ & $\begin{array}{c}\text { Standard } \\
\text { deviation } \\
(7)\end{array}$ & $\begin{array}{c}\text { of } \\
\text { variation } \\
(8) \\
\%\end{array}$ & & \\
\hline $4 \cdot 5$ & 18 & $41 \cdot 36$ & 1.56 & 3.8 & $39 \cdot 08$ & $3 \cdot 10$ & $7 \cdot 9$ & - & - \\
\hline $5 \cdot 0$ & 92 & $41 \cdot 32$ & $1 \cdot 67$ & $4 \cdot 0$ & $39 \cdot 26$ & $4 \cdot 46$ & $11 \cdot 4$ & 0.5510 & 1.47 \\
\hline $5 \cdot 5$ & 132 & $42 \cdot 70$ & 1.73 & $4 \cdot 1$ & $42 \cdot 29$ & $4 \cdot 28$ & $10 \cdot 1$ & 0.7336 & 1.82 \\
\hline $6 \cdot 0$ & 126 & $43 \cdot 43$ & 2.08 & 4.8 & 43.84 & $5 \cdot 22$ & 11.9 & 0.8069 & $2 \cdot 03$ \\
\hline $6 \cdot 5$ & 112 & $44 \cdot 65$ & 1.88 & $4 \cdot 2$ & 46.58 & 4.65 & $10 \cdot 0$ & 0.7405 & 1.82 \\
\hline $7 \cdot 0$ & 156 & 45.94 & 2.07 & $4 \cdot 5$ & $48 \cdot 66$ & $6 \cdot 52$ & $13 \cdot 4$ & 0.8047 & $2 \cdot 53$ \\
\hline $7 \cdot 5$ & 140 & 46.94 & 2.04 & $4 \cdot 4$ & $50 \cdot 68$ & $6 \cdot 01$ & 11.9 & 0.7942 & $2 \cdot 33$ \\
\hline $8 \cdot 0$ & 156 & $48 \cdot 22$ & $2 \cdot 05$ & $4 \cdot 3$ & 54.01 & $6 \cdot 52$ & $12 \cdot 1$ & 0.7883 & $2 \cdot 51$ \\
\hline $8 \cdot 5$ & 150 & $49 \cdot 24$ & $2 \cdot 00$ & $4 \cdot 1$ & $56 \cdot 78$ & $6 \cdot 54$ & 11.5 & 0.7244 & $2 \cdot 37$ \\
\hline $9 \cdot 0$ & 180 & $50 \cdot 07$ & $2 \cdot 12$ & $4 \cdot 2$ & $59 \cdot 08$ & $6 \cdot 60$ & $11 \cdot 1$ & 0.7702 & $2 \cdot 40$ \\
\hline $9 \cdot 5$ & 164 & 51.25 & 2.09 & $4 \cdot 1$ & $62 \cdot 40$ & $7 \cdot 25$ & $11 \cdot 6$ & 0.7014 & 2.43 \\
\hline $10 \cdot 0$ & 157 & 51.98 & $2 \cdot 29$ & $4 \cdot 4$ & 64.99 & $7 \cdot 97$ & $12 \cdot 3$ & 0.7227 & 2.52 \\
\hline 10.5 & 148 & $52 \cdot 80$ & $2 \cdot 28$ & $4 \cdot 3$ & $66 \cdot 68$ & $9 \cdot 12$ & $13 \cdot 7$ & 0.6954 & $2 \cdot 78$ \\
\hline $11 \cdot 0$ & 164 & $53 \cdot 76$ & $2 \cdot 35$ & $4 \cdot 4$ & $70 \cdot 29$ & $9 \cdot 62$ & $13 \cdot 7$ & 0.7601 & $3 \cdot 12$ \\
\hline 11.5 & 166 & $54 \cdot 89$ & $2 \cdot 23$ & $4 \cdot 1$ & 74.06 & $9 \cdot 35$ & $12 \cdot 6$ & 0.7463 & $3 \cdot 12$ \\
\hline 12.0 & 133 & $55 \cdot 82$ & 2.59 & $4 \cdot 6$ & $78 \cdot 19$ & 11.57 & $14 \cdot 8$ & 0.8189 & 3.65 \\
\hline $12 \cdot 5$ & 165 & 57.09 & $2 \cdot 98$ & $5 \cdot 2$ & 83.43 & $12 \cdot 64$ & $15 \cdot 2$ & 0.8419 & $3 \cdot 57$ \\
\hline $13 \cdot 0$ & 182 & $58 \cdot 37$ & $2 \cdot 96$ & $5 \cdot \overline{1}$ & $89 \cdot 12$ & 14.95 & $16 \cdot \overline{8}$ & 0.7926 & 4.00 \\
\hline $13 \cdot 5$ & 140 & $58 \cdot 81$ & 3.09 & $5 \cdot 3$ & 91.25 & 14.95 & $16 \cdot 4$ & 0.8777 & $4 \cdot 25$ \\
\hline $14 \cdot 0$ & 104 & $59 \cdot 34$ & $2 \cdot 64$ & 4.5 & $93 \cdot 64$ & $13 \cdot 62$ & $14 \cdot 6$ & 0.8232 & 4.25 \\
\hline
\end{tabular}

Table II. Isle of Ely. Girls.

\begin{tabular}{|c|c|}
\hline $\begin{array}{c}\text { Age in } \\
\text { years [age } \\
\text { shown is } \\
\text { midpoint } \\
\text { of group] } \\
\text { (1) }\end{array}$ & $\begin{array}{l}\text { No. of } \\
\text { observa } \\
\text { tions } \\
\text { (2) }\end{array}$ \\
\hline $5 \cdot 0$ & 51 \\
\hline 5.5 & 104 \\
\hline 6.0 & 114 \\
\hline 6.5 & 116 \\
\hline $7 \cdot 0$ & 128 \\
\hline 7.5 & 120 \\
\hline 8.0 & 121 \\
\hline 8.5 & 118 \\
\hline 9.0 & 145 \\
\hline 9.5 & 121 \\
\hline 10.0 & 159 \\
\hline 10.5 & 131 \\
\hline 11.0 & 155 \\
\hline 11.5 & 146 \\
\hline 12.0 & 133 \\
\hline 12.5 & 155 \\
\hline 13.0 & 176 \\
\hline 13.5 & 109 \\
\hline 14.0 & 88 \\
\hline
\end{tabular}

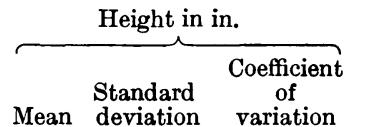

\begin{tabular}{|c|c|c|c|c|}
\hline \multicolumn{3}{|c|}{ Weight in lb. } & $\begin{array}{l}\text { Coefficient } \\
\text { of correla- }\end{array}$ & \\
\hline $\begin{array}{c}\text { Mean } \\
(6)\end{array}$ & $\begin{array}{c}\text { Standard } \\
\text { deviation } \\
(7)\end{array}$ & $\begin{array}{c}\text { Coefficient } \\
\text { of } \\
\text { variation } \\
(8) \\
\%\end{array}$ & $\begin{array}{l}\text { tion between } \\
\text { height and } \\
\text { weight } \\
\text { (9) } \\
+\end{array}$ & $\begin{array}{l}\text { of regres- } \\
\text { sion, weight } \\
\text { on height } \\
\text { (10) }\end{array}$ \\
\hline $38 \cdot 21$ & 3.96 & $10 \cdot 4$ & 0.8606 & $1 \cdot 96$ \\
\hline $40 \cdot 10$ & $4 \cdot 50$ & $11 \cdot 2$ & 0.7857 & 1.90 \\
\hline 41.90 & $4 \cdot 85$ & $11 \cdot 6$ & 0.7431 & $1 \cdot 76$ \\
\hline 45.96 & $6 \cdot 35$ & $13 \cdot 8$ & $0 \cdot 7162$ & $2 \cdot 36$ \\
\hline $46 \cdot 55$ & $5 \cdot 20$ & $11 \cdot 1$ & 0.7595 & $2 \cdot 10$ \\
\hline $50 \cdot 50$ & $7 \cdot 21$ & $14 \cdot 3$ & 0.7388 & $2 \cdot 65$ \\
\hline 53.08 & $7 \cdot 31$ & $13 \cdot 8$ & 0.8220 & $3 \cdot 17$ \\
\hline 54.03 & $6 \cdot 66$ & $12 \cdot 3$ & 0.7761 & 2.53 \\
\hline $56 \cdot 73$ & $8 \cdot 82$ & $15 \cdot 5$ & 0.7707 & $2 \cdot 74$ \\
\hline $60 \cdot 31$ & $9 \cdot 88$ & $16 \cdot 4$ & 0.7581 & $3 \cdot 00$ \\
\hline $63 \cdot 63$ & 9.98 & $15 \cdot 7$ & 0.7036 & $2 \cdot 84$ \\
\hline $66 \cdot 56$ & $11 \cdot 40$ & $17 \cdot 1$ & 0.7846 & $3 \cdot 41$ \\
\hline $72 \cdot 06$ & 14.50 & $20 \cdot 1$ & 0.7712 & $3 \cdot 82$ \\
\hline 75.06 & $13 \cdot 18$ & $17 \cdot 6$ & 0.7964 & $3 \cdot 64$ \\
\hline $80 \cdot 18$ & $14 \cdot 02$ & $17 \cdot 5$ & 0.7239 & $3 \cdot 54$ \\
\hline 85.93 & $17 \cdot 49$ & $20 \cdot 4$ & 0.7422 & $4 \cdot 65$ \\
\hline $91 \cdot 17$ & $16 \cdot 50$ & $18 \cdot 1$ & 0.8065 & $4 \cdot 56$ \\
\hline 92.07 & $14 \cdot 60$ & 15.9 & 0.6657 & $3 \cdot 65$ \\
\hline $99 \cdot 41$ & $15 \cdot 11$ & $15 \cdot 2$ & 0.5843 & $3 \cdot 87$ \\
\hline
\end{tabular}

WEIGHT.

In weight the boys are found to be heavier than the girls up till the 11th year, but thereafter the position is reversed, and girls are definitely the heavier. These findings are in accordance with those of other observers. 
The differences in the rate of growth are shown in the following figures.

Increase in weight.

\begin{tabular}{|c|c|c|c|c|}
\hline \multirow[b]{2}{*}{ Age } & \multicolumn{2}{|c|}{$\underbrace{\text { Boys }}$} & \multicolumn{2}{|c|}{ Girls } \\
\hline & Isle of Ely & East Sussex & Isle of Ely & East Sussex \\
\hline \multicolumn{5}{|c|}{ Total increase in pounds. } \\
\hline $\begin{array}{l}6-9 \\
9-13\end{array}$ & $\begin{array}{l}15 \cdot 2 \\
30 \cdot 0\end{array}$ & $\begin{array}{l}13 \cdot 0 \\
21 \cdot 8\end{array}$ & $\begin{array}{l}14 \cdot 8 \\
34 \cdot 4\end{array}$ & $\begin{array}{l}13 \cdot 3 \\
27 \cdot 0\end{array}$ \\
\hline \multicolumn{5}{|c|}{ Mean increase in pounds per year. } \\
\hline $\begin{array}{l}6-9 \\
9-13\end{array}$ & $\begin{array}{l}5 \cdot 07 \\
7 \cdot 50\end{array}$ & $\begin{array}{l}4 \cdot 33 \\
5 \cdot 45\end{array}$ & $\begin{array}{l}4 \cdot 93 \\
8 \cdot 60\end{array}$ & $\begin{array}{l}4 \cdot 44 \\
6 \cdot 75\end{array}$ \\
\hline
\end{tabular}

The mean increase is slightly greater in boys than in girls in the Isle of Ely figures during the 6-9 period but the reverse is the case in East Sussex. In both areas the increase is distinctly greater in girls of 9-13 compared with boys of the same age. As with height there is a greater increase in both sexes and in both age groups in the Isle of Ely than in East Sussex.

\section{VARIABILITY OF HEIGHT AND WEIGHT.}

In both sexes, with increase in age, there is a greater scatter of the observations around the mean, especially in the observations of weight. Weight, in . fact, at each age is much more variable than height, and the degree of variability increases with age, somewhat more noticeably in the case of girls. There is a high correlation between weight and height at these ages. The coefficients for each age are shown in Tables I and II. They differ but slightly at different ages or between the sexes.

\section{REGRESSION OF WEIGHT ON HEIGHT.}

Column 10 in Tables I and II gives the average increase in weight per inch of height at each half-year (the calculated regression coefficient). It will be seen that the average increase in weight for each inch of height becomes greater with age, but the increase is not uniform, an observation in accord with common knowledge. It may also be noted that the period of maximum increase in weight for each inch of height occurs at a later period in boys than in girls. This is again in accordance with other observations. Girls in most age groups show a greater average increase in weight for a unit change in height than boys.

The observed regression of weight on height irrespective of age, i.e. the mean weight for each inch of height, is shown in Tables III and IV. The figures show that except at heights 56.75 and $57.75 \mathrm{in}$. boys are heavier than girls at any given height. The fact that these weight for height figures, irrespective of age, show that boys are heavier than girls, while in the separate age groups the older girls are heavier and taller than the boys, can probably be explained by the earlier onset of puberty in girls, and in consequence increased growth in their case from round about the 12 th year. It is a pity that figures were not available for children of the elementary school class for the higher 
ages up to about 18 years. Changes beyond the age of 14 years would be of considerable interest.

Table III. The Isle of Ely. Standards of weight per inch of height. Boys.

$\begin{array}{ccccc}\begin{array}{c}\text { Number of } \\ \text { observations }\end{array} & \begin{array}{c}\text { Height } \\ \text { in inches }\end{array} & \begin{array}{c}\text { Mean weight } \\ \text { in lb. }\end{array} & \begin{array}{c}\text { Standard } \\ \text { deviation } \\ \text { of weight }\end{array} & \begin{array}{c}\text { Nutritional } \\ \text { quotient } \\ =W / H\end{array} \\ 15 & 38 \cdot 75- & 36 \cdot 65 & 1 \cdot 67 & 0 \cdot 93 \\ 37 & 39 \cdot 75- & 36 \cdot 87 & 2 \cdot 17 & 0 \cdot 92 \\ 77 & 40 \cdot 75- & 39 \cdot 06 & 2 \cdot 57 & 0 \cdot 95 \\ 91 & 41 \cdot 75- & 40 \cdot 92 & 2 \cdot 53 & 0 \cdot 97 \\ 115 & 42 \cdot 75- & 42 \cdot 82 & 2 \cdot 87 & 0 \cdot 99 \\ 107 & 43 \cdot 75- & 45 \cdot 27 & 3 \cdot 01 & 1 \cdot 02 \\ 117 & 44 \cdot 75- & 46 \cdot 91 & 3 \cdot 28 & 1 \cdot 04 \\ 112 & 45 \cdot 75- & 49 \cdot 30 & 3 \cdot 03 & 1 \cdot 07 \\ 142 & 46 \cdot 75- & 51 \cdot 76 & 3 \cdot 72 & 1 \cdot 10 \\ 145 & 47 \cdot 75- & 54 \cdot 23 & 3 \cdot 68 & 1 \cdot 12 \\ 166 & 48 \cdot 75- & 56 \cdot 80 & 4 \cdot 65 & 1 \cdot 15 \\ 179 & 49 \cdot 75- & 59 \cdot 36 & 4 \cdot 12 & 1 \cdot 18 \\ 173 & 50 \cdot 75- & 61 \cdot 96 & 4 \cdot 33 & 1 \cdot 21 \\ 178 & 51 \cdot 75- & 65 \cdot 49 & 4 \cdot 44 & 1 \cdot 25 \\ 149 & 52 \cdot 75- & 68 \cdot 36 & 4 \cdot 99 & 1 \cdot 28 \\ 147 & 53 \cdot 75- & 72 \cdot 10 & 5 \cdot 70 & 1 \cdot 33 \\ 151 & 54 \cdot 75- & 75 \cdot 21 & 5 \cdot 98 & 1 \cdot 36 \\ 155 & 55 \cdot 75- & 79 \cdot 06 & 8 \cdot 01 & 1 \cdot 41 \\ 125 & 56 \cdot 75- & 82 \cdot 93 & 7 \cdot 17 & 1 \cdot 45 \\ 111 & 57 \cdot 75- & 86 \cdot 30 & 7 \cdot 37 & 1 \cdot 48 \\ 88 & 58 \cdot 75- & 92 \cdot 34 & 8 \cdot 05 & 1 \cdot 56 \\ 84 & 59 \cdot 75- & 95 \cdot 52 & 8 \cdot 18 & 1 \cdot 59 \\ 47 & 60 \cdot 75- & 100 \cdot 55 & 10 \cdot 68 & 1 \cdot 64 \\ 32 & 61 \cdot 75- & 104 \cdot 28 & 11 \cdot 92 & 1 \cdot 68 \\ 18 & 62 \cdot 75-63 \cdot 74 & 109 \cdot 19 & 7 \cdot 99 & 1 \cdot 73 \\ & & & & \end{array}$

Table IV. The Isle of Ely. Standards of weight per inch of height. Girls.

$\begin{array}{ccccc}\begin{array}{c}\text { Number of } \\ \text { observations }\end{array} & \begin{array}{c}\text { Height } \\ \text { in inches }\end{array} & \begin{array}{c}\text { Mean weight } \\ \text { in lb. }\end{array} & \begin{array}{c}\text { Standard } \\ \text { deviation } \\ \text { of weight }\end{array} & \begin{array}{c}\text { Nutritional } \\ \text { quotient } \\ =W / H\end{array} \\ 20 & 38 \cdot 75- & 34 \cdot 35 & 1 \cdot 55 & 0 \cdot 87 \\ 41 & 39 \cdot 75- & 36 \cdot 42 & 2 \cdot 17 & 0 \cdot 90 \\ 50 & 40 \cdot 75- & 38 \cdot 37 & 2 \cdot 66 & 0 \cdot 93 \\ 75 & 41 \cdot 75- & 40 \cdot 02 & 2 \cdot 73 & 0 \cdot 95 \\ 78 & 42 \cdot 75- & 41 \cdot 93 & 3 \cdot 09 & 0 \cdot 97 \\ 98 & 43 \cdot 75- & 44 \cdot 03 & 2 \cdot 79 & 1 \cdot 00 \\ 89 & 44 \cdot 75- & 46 \cdot 12 & 3 \cdot 22 & 1 \cdot 02 \\ 119 & 45 \cdot 75- & 47 \cdot 89 & 3 \cdot 64 & 1 \cdot 04 \\ 135 & 46 \cdot 75- & 50 \cdot 20 & 3 \cdot 39 & 1 \cdot 06 \\ 139 & 47 \cdot 75- & 52 \cdot 35 & 3 \cdot 98 & 1 \cdot 08 \\ 107 & 48 \cdot 75- & 55 \cdot 31 & 4 \cdot 70 & 1 \cdot 12 \\ 139 & 49 \cdot 75- & 57 \cdot 86 & 5 \cdot 03 & 1 \cdot 15 \\ 144 & 50 \cdot 75- & 61 \cdot 18 & 6 \cdot 03 & 1 \cdot 19 \\ 118 & 51 \cdot 75- & 62 \cdot 90 & 4 \cdot 91 & 1 \cdot 20 \\ 123 & 52 \cdot 75- & 66 \cdot 05 & 6 \cdot 60 & 1 \cdot 24 \\ 111 & 53 \cdot 75- & 70 \cdot 67 & 7 \cdot 35 & 1 \cdot 30 \\ 109 & 54 \cdot 75- & 73 \cdot 67 & 9 \cdot 60 & 1 \cdot 33 \\ 119 & 55 \cdot 75- & 77 \cdot 80 & 9 \cdot 16 & 1 \cdot 38 \\ 97 & 56 \cdot 75- & 84 \cdot 07 & 11 \cdot 02 & 1 \cdot 47 \\ 117 & 57 \cdot 75- & 88 \cdot 70 & 11 \cdot 53 & 1 \cdot 52 \\ 102 & 58 \cdot 75- & 92 \cdot 25 & 12 \cdot 21 & 1 \cdot 56 \\ 76 & 59 \cdot 75- & 94 \cdot 36 & 11 \cdot 98 & 1 \cdot 57 \\ 75 & 60 \cdot 75- & 100 \cdot 05 & 11 \cdot 08 & 1 \cdot 63 \\ 59 & 61 \cdot 75- & 102 \cdot 00 & 11 \cdot 62 & 1 \cdot 64 \\ 28 & 62 \cdot 75-63 \cdot 74 & 108 \cdot 50 & 15 \cdot 21 & 1 \cdot 72 \\ & & & & \end{array}$


Comparative figures.

In Tables V-VIII the observations from the Isle of Ely are compared with figures from other areas. The most noticeable feature is the superiority of the Isle of Ely children both as regards height and weight, more especially at the higher ages.

Table V. Boys. Height in inches.

\begin{tabular}{|c|c|c|c|c|c|c|c|}
\hline \multirow{2}{*}{$\begin{array}{c}\text { Ages in } \\
\text { years }\end{array}$} & \multirow[b]{2}{*}{$\begin{array}{l}\text { Isle of } \\
\text { Ely }\end{array}$} & \multicolumn{2}{|c|}{ Tuxford and Glegg, 1911} & \multirow{2}{*}{$\begin{array}{c}\text { Dunstan, } \\
1925 \\
\text { (East } \\
\text { Sussex) }\end{array}$} & \multirow[b]{2}{*}{$\begin{array}{c}\text { McKinlay, } \\
1924 \\
\text { (Glasgow) }\end{array}$} & \multirow[b]{2}{*}{$\begin{array}{c}\text { Leeds } \\
\text { Report, } \\
1930\end{array}$} & \multirow{2}{*}{$\begin{array}{l}\text { Board of } \\
\text { Education } \\
\text { Anthrop. } \\
\text { Committee }\end{array}$} \\
\hline & & England & $\begin{array}{c}\text { County } \\
\text { areas }\end{array}$ & & & & \\
\hline 5 & $41 \cdot 32$ & - & - & $40 \cdot 79$ & - & - & $41 \cdot 4$ \\
\hline $5 \frac{1}{2}$ & $42 \cdot 70$ & 40.55 & $40 \cdot 63$ & 41.83 & - & $41 \cdot 6$ & \\
\hline 6 & $43 \cdot 43$ & - & - & $42 \cdot 71$ & - & & $43 \cdot 0$ \\
\hline $6 \frac{1}{2}$ & $44 \cdot 65$ & $42 \cdot 52$ & $42 \cdot 76$ & $43 \cdot 87$ & - & $44 \cdot 3$ & \\
\hline $7^{2}$ & 45.94 & & - & 44.95 & - & - & $45 \cdot 4$ \\
\hline $7 \frac{1}{2}$ & $46 \cdot 94$ & $45 \cdot 16$ & $4 \widetilde{5 \cdot 39}$ & $45 \cdot 97$ & - & $46 \cdot 8$ & - \\
\hline $8^{2}$ & $48 \cdot 22$ & & - & $47 \cdot 13$ & $46 \cdot 25$ & - & $47 \cdot 8$ \\
\hline $8 \frac{1}{2}$ & $49 \cdot 24$ & $46 \cdot 97$ & $47 \cdot 05$ & $48 \cdot 24$ & - & $47 \cdot 6$ & \\
\hline $9^{2}$ & 50.07 & - & & $49 \cdot 04$ & $47 \cdot 77$ & & $49 \cdot 2$ \\
\hline $9 \frac{1}{2}$ & $51 \cdot 25$ & 49.09 & $49 \cdot 84$ & $50 \cdot 33$ & - & $49 \cdot 8$ & \\
\hline $10^{2}$ & 51.98 & - & - & 50.91 & $49 \cdot 96$ & - & $51 \cdot 3$ \\
\hline $10 \frac{1}{2}$ & $52 \cdot 80$ & 50.95 & $51 \cdot 18$ & $51 \cdot 63$ & - & $51 \cdot 5$ & \\
\hline $11{ }^{2}$ & $53 \cdot 76$ & - & & $52 \cdot 63$ & $51 \cdot 67$ & & $52 \cdot 7$ \\
\hline $11 \frac{1}{2}$ & $54 \cdot 89$ & $52 \cdot 84$ & $53 \cdot 23$ & $\begin{array}{l}53.58 \\
53.08\end{array}$ & - & $\overline{54 \cdot 2}$ & \\
\hline 12 & 55.82 & & & $54 \cdot 51$ & $52 \cdot 71$ & & $55 \cdot 0$ \\
\hline $12 \frac{1}{2}$ & $57 \cdot 09$ & $55 \cdot 04$ & $55 \cdot 20$ & $55 \cdot 54$ & - & $54 \cdot 8$ & \\
\hline 13 & $58 \cdot 37$ & - & & $56 \cdot 38$ & $54 \cdot 71$ & & $56 \cdot 2$ \\
\hline $13 \frac{1}{2}$ & $58 \cdot 81$ & $56 \cdot 10$ & $56 \cdot 14$ & $56 \cdot 88$ & - & $57 \cdot 1$ & - \\
\hline 14 & $59 \cdot 34$ & - & - & 58.00 & - & - & $58 \cdot 0$ \\
\hline
\end{tabular}

Table VI. Boys. Weight in pounds.

\begin{tabular}{|c|c|c|c|c|c|c|c|}
\hline \multirow{2}{*}{$\begin{array}{c}\text { Ages in } \\
\text { years }\end{array}$} & \multirow[b]{2}{*}{$\begin{array}{l}\text { Isle of } \\
\text { Ely }\end{array}$} & \multicolumn{2}{|c|}{ Tuxford and Glegg, 1911} & \multirow{2}{*}{$\begin{array}{l}\text { Dunstan, } \\
1925 \\
\text { (East } \\
\text { Sussex) }\end{array}$} & \multirow[b]{2}{*}{$\begin{array}{c}\text { McKinlay, } \\
1924 \\
\text { (Glasgow) }\end{array}$} & \multirow[b]{2}{*}{$\begin{array}{c}\text { Leeds } \\
\text { Report, } \\
1930\end{array}$} & \multirow{2}{*}{$\begin{array}{c}\text { Board of } \\
\text { Education } \\
\text { Anthrop. } \\
\text { Committee }\end{array}$} \\
\hline & & England & $\begin{array}{l}\text { County } \\
\text { areas }\end{array}$ & & & & \\
\hline 5 & $39 \cdot 26$ & & & $38 \cdot 23$ & - & - & $38 \cdot 7$ \\
\hline $5 \frac{1}{2}$ & $42 \cdot 29$ & 38.58 & 38.96 & 40.54 & - & $40 \cdot 2$ & - \\
\hline 6 & $43 \cdot 84$ & - & - & 41.71 & - & - & $41 \cdot 3$ \\
\hline $6 \frac{1}{2}$ & $46 \cdot 58$ & $42 \cdot 52$ & $42 \cdot 57$ & $43 \cdot 65$ & - & $44 \cdot 0$ & \\
\hline $7^{2}$ & $48 \cdot 66$ & & & $45 \cdot 46$ & - & & $45 \cdot 4$ \\
\hline $7 \frac{1}{2}$ & $50 \cdot 68$ & $46 \cdot 64$ & $47 \cdot 23$ & 47.94 & - & $50 \cdot 0$ & \\
\hline & 54.01 & - & - & $50 \cdot 26$ & $50 \cdot 85$ & - & $51 \cdot 0$ \\
\hline $8 \frac{1}{2}$ & $56 \cdot 78$ & $50 \cdot 29$ & $51 \cdot 26$ & $53 \cdot 56$ & - & $53 \cdot 8$ & \\
\hline 9 & $59 \cdot 08$ & & - & $54 \cdot 63$ & $55 \cdot 44$ & & $54 \cdot 8$ \\
\hline $9 \frac{1}{2}$ & $62 \cdot 40$ & $55 \cdot 26$ & $56 \cdot 89$ & $58 \cdot 26$ & - & 58.5 & \\
\hline $10^{\frac{2}{2}}$ & 64.99 & - & - & $\begin{array}{l}59 \cdot 36 \\
59 \cdot 20\end{array}$ & $60 \cdot 55$ & & $\overline{59 \cdot 6}$ \\
\hline $10 \frac{1}{2}$ & 66.68 & $60 \cdot 32$ & $61 \cdot 05$ & $61 \cdot 88$ & - & $63 \cdot 2$ & - \\
\hline 112 & $70 \cdot 29$ & - & - & 64.92 & $65 \cdot 02$ & & $64 \cdot 6$ \\
\hline $11 \frac{1}{2}$ & 74.06 & $65 \cdot 84$ & $67 \cdot 71$ & $67 \cdot 72$ & - & $72 \cdot 0$ & \\
\hline 12 & $78 \cdot 19$ & & & $70 \cdot 36$ & $68 \cdot 40$ & & $71 \cdot 6$ \\
\hline $12 \frac{1}{2}$ & $83 \cdot 43$ & $72 \cdot 71$ & $73 \cdot 28$ & $73 \cdot 87$ & - & $74 \cdot 2$ & \\
\hline 13 & $89 \cdot 12$ & & & $77 \cdot 21$ & 74.99 & & $76 \cdot 5$ \\
\hline $13 \frac{1}{2}$ & 91.25 & $77 \cdot 33$ & $77 \cdot 70$ & $79 \cdot 08$ & - & $82 \cdot 1$ & - \\
\hline 14 & 93.64 & - & - & $85 \cdot 40$ & - & - & $86 \cdot 1$ \\
\hline
\end{tabular}

For instance in comparison with the observations of the Board of Education Anthropological Committee (1927, The Health of the School Child, p. 138), the Isle of Ely children are on the average slightly less in height at the initial age, 5 years, but at ages 6-8 are approximately half an inch taller, at ages 9-12 
three-quarters to an inch taller, and at ages 13-14 between one and two inches taller. Similarly the Isle of Ely children do not differ materially in weight at age 5 from the children measured by the Anthropometric Committee, but at ages $6-8$ are some 2-3 lb. heavier, at ages $9-12$ between 4 and $6 \mathrm{lb}$. heavier, and

Table VII. Girls. Height in inches.

\begin{tabular}{|c|c|c|c|c|c|c|c|}
\hline $\begin{array}{c}\text { Ages in } \\
\text { years }\end{array}$ & $\begin{array}{l}\text { Isle of } \\
\text { Ely }\end{array}$ & Tuxford an & $\frac{\text { Glegg, } 1911}{\begin{array}{c}\text { County } \\
\text { areas }\end{array}}$ & $\begin{array}{c}\text { Dunstan, } \\
1925 \\
\text { (East } \\
\text { Sussex) }\end{array}$ & $\begin{array}{c}\text { McKinlay, } \\
\text { 1924 } \\
\text { (Glasgow) }\end{array}$ & $\begin{array}{c}\text { Leeds } \\
\text { Report, } \\
1930\end{array}$ & $\begin{array}{l}\text { Board of } \\
\text { Education } \\
\text { Anthrop. } \\
\text { Committee }\end{array}$ \\
\hline 5 & $40 \cdot 86$ & - & - & $40 \cdot 32$ & - & - & $41 \cdot 1$ \\
\hline $5 \frac{1}{2}$ & $42 \cdot 13$ & $40 \cdot 39$ & $40 \cdot 59$ & $41 \cdot 54$ & - & $41 \cdot 4$ & \\
\hline 6 & $43 \cdot 28$ & - & - & $42 \cdot 65$ & - & - & $42 \cdot 8$ \\
\hline $6 \frac{1}{2}$ & $44 \cdot 93$ & $42 \cdot 36$ & $42 \cdot 52$ & $43 \cdot 43$ & - & $43 \cdot 5$ & - \\
\hline $7^{2}$ & $45 \cdot 61$ & - & - & $44 \cdot 43$ & - & - & $45 \cdot 1$ \\
\hline $7 \frac{1}{2}$ & $47 \cdot 16$ & $44 \cdot 84$ & $45 \cdot 12$ & $45 \cdot 90$ & - & $46 \cdot 4$ & - \\
\hline $8^{2}$ & $48 \cdot 21$ & - & - & $47 \cdot 17$ & $46 \cdot 00$ & - & $47 \cdot 5$ \\
\hline $8 \frac{1}{2}$ & $48 \cdot 90$ & $46 \cdot 30$ & $46 \cdot 38$ & $47 \cdot 88$ & - & $47 \cdot 9$ & - \\
\hline 9 & $49 \cdot 73$ & - & - & $48 \cdot 89$ & $47 \cdot 88$ & - & $48 \cdot 9$ \\
\hline $9 \frac{1}{2}$ & $50 \cdot 99$ & $48 \cdot 70$ & $49 \cdot 45$ & $49 \cdot 50$ & - & $49 \cdot 8$ & - \\
\hline $10^{2}$ & $52 \cdot 01$ & - & - & $50 \cdot 75$ & $49 \cdot 57$ & - & $51 \cdot 2$ \\
\hline $10 \frac{1}{2}$ & 53.02 & $51 \cdot 10$ & $51 \cdot 26$ & $52 \cdot 02$ & - & $51 \cdot 4$ & - \\
\hline 11 & $54 \cdot 00$ & - & - & $52 \cdot 83$ & $51 \cdot 13$ & - & $52 \cdot 8$ \\
\hline $11 \frac{1}{2}$ & $55 \cdot 35$ & $52 \cdot 56$ & $53 \cdot 39$ & $53 \cdot 81$ & - & $53 \cdot 9$ & - \\
\hline 12 & $56 \cdot 85$ & - & - & $55 \cdot 18$ & $53 \cdot 38$ & - & $55 \cdot 6$ \\
\hline $12 \frac{1}{2}$ & $57 \cdot 90$ & $54 \cdot 61$ & $54 \cdot 53$ & $56 \cdot 46$ & - & $55 \cdot 6$ & - \\
\hline 13 & $59 \cdot 23$ & - & - & $57 \cdot 84$ & $56 \cdot 00$ & - & 56.9 \\
\hline $13 \frac{1}{2}$ & $59 \cdot 40$ & $56 \cdot 89$ & $57 \cdot 12$ & $58 \cdot 56$ & - & $57 \cdot 3$ & - \\
\hline 14 & $60 \cdot 85$ & - & - & $59 \cdot 77$ & - & - & 58.9 \\
\hline $14 \frac{1}{2}$ & - & $58 \cdot 66$ & 58.98 & - & - & - & - \\
\hline
\end{tabular}

Table VIII. Girls. Weight in pounds.

\begin{tabular}{|c|c|c|c|c|c|c|c|}
\hline $\begin{array}{c}\text { Ages in } \\
\text { years }\end{array}$ & $\begin{array}{l}\text { Isle of } \\
\text { Ely }\end{array}$ & England & $\begin{array}{c}\text { County } \\
\text { areas }\end{array}$ & $\begin{array}{c}1925 \\
\text { (East } \\
\text { Sussex) }\end{array}$ & $\begin{array}{c}\text { McKinlay, } \\
1924 \\
\text { (Glasgow) }\end{array}$ & $\begin{array}{c}\text { Leeds } \\
\text { Report, } \\
1930\end{array}$ & $\begin{array}{l}\text { Education } \\
\text { Anthrop. } \\
\text { Committee }\end{array}$ \\
\hline 5 & $38 \cdot 21$ & - & - & $37 \cdot 50$ & - & - & $37 \cdot 5$ \\
\hline $5 \frac{1}{2}$ & $40 \cdot 10$ & $37 \cdot 55$ & $37 \cdot 88$ & $39 \cdot 38$ & - & $38 \cdot 9$ & - \\
\hline 6 & $41 \cdot 90$ & - & - & $41 \cdot 36$ & - & - & $40 \cdot 1$ \\
\hline $6 \frac{1}{2}$ & $45 \cdot 96$ & $40 \cdot 88$ & $41 \cdot 02$ & $42 \cdot 12$ & - & $42 \cdot \tilde{5}$ & - \\
\hline 7 & $46 \cdot 55$ & - & - & $45 \cdot 00$ & 一 & - & $44 \cdot 4$ \\
\hline $7 \frac{1}{2}$ & $50 \cdot 50$ & $44 \cdot 89$ & $45 \cdot 19$ & $47 \cdot 39$ & - & $48 \cdot 6$ & - \\
\hline 8 & $53 \cdot 08$ & - & - & $49 \cdot 44$ & $49 \cdot 48$ & - & $49 \cdot 4$ \\
\hline $8 \frac{1}{2}$ & $54 \cdot 03$ & $48 \cdot 82$ & $48 \cdot 88$ & $51 \cdot 22$ & - & $52 \cdot 0$ & - \\
\hline 9 & $56 \cdot 73$ & - & - & $53 \cdot 40$ & 53.91 & - & $52 \cdot 6$ \\
\hline $9 \frac{1}{2}$ & $60 \cdot 31$ & $54 \cdot 44$ & $55 \cdot 22$ & $56 \cdot 57$ & - & $56 \cdot 5$ & - \\
\hline 10 & $63 \cdot 63$ & - & - & $58 \cdot 82$ & $57 \cdot 39$ & - & $59 \cdot 8$ \\
\hline $10 \frac{1}{2}$ & $66 \cdot 56$ & $58 \cdot 66$ & $59 \cdot 27$ & $62 \cdot 55$ & - & $62 \cdot 3$ & - \\
\hline 11 & $72 \cdot 06$ & - & - & $64 \cdot 57$ & $61 \cdot 29$ & 一 & $63 \cdot 9$ \\
\hline $11 \frac{1}{2}$ & $75 \cdot 06$ & $65 \cdot 08$ & $66 \cdot 68$ & $68 \cdot 20$ & - & $70 \cdot 0$ & - \\
\hline 12 & $80 \cdot 18$ & - & - & $71 \cdot 29$ & $69 \cdot 43$ & - & $73 \cdot 9$ \\
\hline $12 \frac{1}{2}$ & $85 \cdot 93$ & $73 \cdot 72$ & $74 \cdot 45$ & $75 \cdot 34$ & - & $75 \cdot 9$ & - \\
\hline 13 & $91 \cdot 17$ & - & - & $81 \cdot 89$ & $78 \cdot 48$ & - & $79 \cdot 0$ \\
\hline $13 \frac{1}{2}$ & $92 \cdot 07$ & $79 \cdot 88$ & 80.94 & $85 \cdot 74$ & - & $81 \cdot 7$ & - \\
\hline 14 & $99 \cdot 41$ & - & - & $88 \cdot 53$ & - & - & $88 \cdot 2$ \\
\hline $14 \frac{1}{2}$ & - & $87 \cdot 58$ & $88 \cdot 26$ & & - & - & - \\
\hline
\end{tabular}

at ages 13-14 as much as 11 or $12 \mathrm{lb}$. heavier. Too much reliance ought not to be placed on the figure for any single group, but there is no doubt as to the general conclusion that, on the average, children in this part of the country are both taller and heavier for their age than those in the other areas for which 
figures are available. That this is probably not merely an advantage of country children over town children is shown by comparison with the figures for East Sussex which refer to a rural population, and with Tuxford and Glegg's (1911) "County Area" figures which refer to a predominantly rural population. There is, however, a time factor to be considered. Tuxford and Glegg's observations are over 20 years old, and Dunstan's measurements for East Sussex refer to children born between 1893 and 1910. The Isle of Ely figures refer to children born between 1918 and 1928. It is therefore possible that the superior height and weight in the Isle of Ely are a measure of social amelioration generally, and perhaps of increased interest and care in child life in more recent years. Thus the Board of Education figures show a superiority as regards both height and weight over those of Tuxford and Glegg both for all areas and for county areas only, though the difference is small. It does, however, exist and since the Board's figures are for all areas, rural and urban, the contrary might rather have been expected. It seems, therefore, a fair assumption that height and weight of school children has slightly but definitely improved in the last 20 years. It would be of considerable value to the study of nutrition if a careful and comprehensive study of relative heights and weights now and, say, 20-25 years ago for different types of areas could be made. The average increase in weight and height for all areas over that period could be determined and compared with that in different areas. It is manifestly not sufficient, in support of the view that nutrition in some areas has not been seriously impaired of recent years, to demonstrate that no change in weight and height over a period of time has taken place, or even that a slight increase has been observed, for perhaps a distinct increase might reasonably have been expected in the absence of adverse environmental influences.

But however this may be, it is not probable that the superiority of the Isle of Ely figures can be explained by the fact that the observations are of more recent date. Almost certainly racial factors are also involved. In order to determine the importance of these, it would be necessary to have weight and height figures preferably for all education areas in the country, but certainly for a sufficient selection of areas, so that broad racial groupings could be made and comparisons drawn, not only between different areas, but between rural and urban populations racially differentiated.

It has already been observed that the Isle of Ely children show their maximum superiority in height and weight at the higher ages. It has been suggested to me that clothes may be a factor at the higher ages, but I do not think this is probable. The only article of dress which is rather different in the country as compared with the town is probably boots, which are heavier in the country. Measurements were, however, made without boots. In addition the majority of observers have found that country children are, on the average, taller and heavier than town children, and the Isle of Ely figures when compared with those of Leeds (Wear, 1931) and Glasgow (McKinlay, 1924) bear this out for both sexes and at all periods, but again more distinctly so at the higher ages. 
It seems to me that a possible explanation of this increasing advantage at the higher ages is due to an earlier onset of puberty in the rural areas. It would, however, be very difficult to determine this, since puberty is a period and its onset cannot be assigned to any particular week or month.

\section{The Weight/height Ratio.}

The simple $W / H$ ratio or nutritional quotient has been set out in Tables III and IV for each height irrespective of age. The ratio for boys is $0 \cdot 02-0 \cdot 04$ higher on the average than that for girls. It seems to me, however, that this figure is of very limited value. If height be constant it is easier to compare weights, and avoid the calculation of the quotient. If, on the other hand, the $W / H$ ratio is worked out for separate age groups, then the quotient is a figure which is of undoubted significance. As regards, however, preliminary investigation of nutrition such as is required most frequently in a school medical inspection, a quick reference in any doubtful case to a table of weight-heightage (such as Tables I and II), or to a simple weight and height table (such as Tables III and IV), would enable any child differing widely from the standard to be picked out for further examination. Some authorities suggest that weight for height irrespective of age is sufficient as a rough index of nutrition, and do not regard age as being a factor of great importance. If one follows this method, remembering normal variations in weight, one can construct, as is done by Emerson (1930) in America, and by Dunstan (1933) in this country, a minimal weight-height table. In this, an agreed percentage is deducted from the observed mean weight per unit of height and all children who are at or below this minimum weight for their height are noted for further investigation of their nutrition. Thus, I have found that, of the children under investigation in the present study, 8.0 per cent. of the boys and 13.2 per cent. of the girls were 10 per cent. or more below the mean weight for their height. But in whatever way they are utilised, weight and height data can never be more than a rough index of nutrition though a very necessary one. They do, however, give a picture of the "size" of the average child, and, even if they are not malnourished, those that differ widely from the scale are not normal and their condition requires further investigation.

Moreover an accumulation of such data for different areas in this country ought to give indications of racial and no less important economic and environmental differences which, if the influences can be elucidated, must guide the community in its strivings after the general betterment of the race.

In conclusion I wish to record my thanks to Dr R. French, County Medical Officer of the Isle of Ely, for making the investigation possible and for permission to publish the results, and to Dr A. Bradford Hill of the Division of Epidemiology and Vital Statistics of the London School of Hygiene and Tropical Medicine, for much help in checking the figures and in the preparation of the article for publication. 


\section{REFERENCES.}

Dunstan, W. R. (1925). Height and Weight of School Children in an English Rural Area. Metron, 5, No. 2.

- (1933). Medical Officer, 49, 16.

Emerson, W. R. P. (1930). The Diagnosis of Health. Appleton.

McKinlay, P. L. (1924). J. of Hygiene, 23, 176.

Tuxford, A. W. and GlegG, R. A. (1911). Brit. Med. J.1, 1423.

Wear, A. E. L. (1931). Report of the School Medical Officer, City of Leeds.

(MS. received for publication 5. I. 1934.-Ed.) 